\title{
Comprehensive Comparison and Analysis of Municipal Sludge Resourceful Treatment Technology
}

\author{
Shuguo Zhang ${ }^{\mathrm{a}}$, Ce Liang ${ }^{\mathrm{b} \text {, * }}$
}

\author{
Department of Economics and Management, North China Electric Power University, Baoding. \\ 071003, China \\ aemail: 13930865901@163.com, bemail:cheige001@163.com, "corresponding author
}

\begin{abstract}
Keywords: Sludge Resourceful Treatment, Anaerobic Digestion, Aerobic Fermentation, Incineration, Comparison
\end{abstract}

\begin{abstract}
China's urban sludge production is still growing, and it can cause secondary pollution if it is not handled properly. Sludge treatment is the process of stabilizing, reducing, harmless and recycling sludge. With the increased importance of sludge, sludge recycling technology develops rapidly. It has been regarded as the fundamental way of sludge disposal and treatment. However, the applicable conditions and technical parameters of line sludge technology are not solidified in our country, so the uncertainty and randomness are still around the choice of technology route. This paper mainly introduced three mainstream sludge disposal technology and made a comprehensive comparison and analysis, and tried to provide basis for the selection of technology on municipal sludge treatment project.
\end{abstract}

\section{Introduction}

Sludge is a by-product of sewage treatment and most of the pollutants in sewage sludge are transferred to them. China's urban sludge production has increased. In 2015, China's annual wastewater treatment plant sludge production had reached 33 million 590 thousand tons (water content of $80 \%$ ), and maintain an annual growth rate of about $8 \%$, and it is expected that it would produce an annual output of more than 40 million tons in 2017. The sewage sludge produced by municipal wastewater treatment plant has high moisture content and high organic content, which is liable to decay and stink. If it is not treated properly, it will cause serious secondary pollution [1]. Therefore, sludge treatment is an important part of wastewater treatment process.

China has always attached importance to sewage treatment, ignoring sludge treatment, sewage, sludge treatment rate does not match seriously. In 2015, China's average sludge disposal rate was less than $30 \%$, and more than $70 \%$ of the sludge flowed into the environment without safe disposal. Compared to sewage treatment, sludge treatment and disposal industry in technology and market maturity are far behind, the two are relatively serious separation. The environmental problems caused by sludge treatment and disposal have become increasingly prominent.

\section{Mainstream Technology of Sludge Recycling}

Sludge treatment is a process of stabilizing, reducing, harmless and recycling sludge, the commonly used processing methods are dehydration, drying, incineration, anaerobic digestion, aerobic fermentation and so on. In addition, thermal hydrolysis, carbonation and CO treatment with organic wastes have begun to appear in the operation market in recent years, but at present, the proportion is still small [2]. With the emphasis on sludge improved, sludge treatment technology developed rapidly, and is more and more widely used. The sludge recycling can meet the needs of sludge stabilization, reduction and harmlessness. It can realize waste energy treatment and waste reduction and energy saving and emission reduction, resulting in great environmental benefits, It is regarded as the fundamental outlet for sludge treatment and disposal.

At present, three mainstream sludge treatment and disposal technology routes have been formed in China: Anaerobic digestion + mixed landfill、Aerobic fermentation + land use incineration + 
building materials utilization. A demonstration project has been established in several cities, and a preliminary technical system for sludge treatment and disposal has been established. However, the demonstration project lacks operational effectiveness evaluation and comprehensive system summary, and the application conditions and technical parameters of the technical route are not solidified. As a result, there is uncertainty and randomness in choosing technology routes. The following article makes a comprehensive comparison and analysis of the three technical routes to provide the basis for the technical route selection of the municipal sludge treatment project in the future.

\section{Comprehensive Comparison of Three Technical Routes}

Anaerobic Digestion + Mixed Landfill. Operational Aspect. The technique first dewatered the sludge to $80 \%$ of the moisture content, and then fed it to the digester. Anaerobic and biochemical reactions were carried out with facultative bacteria and obligate anaerobic bacteria under anaerobic conditions, the organic matter in the sludge into humus, biogas, and reduce the sludge volume. Finally, the sludge is transported to the landfill. The biogas produced into biogas purification workshop, complete desulfurization, decarburization and purification etc. A part of methane gas can be used in sewage plants, biogas boilers and biogas generators. The remaining biogas can be purified and used as fuel for automobiles and civil gas [3].

Cost Analysis. According to the specific circumstances of different treatment process, The unit investment of the project is 250 800 thousand $¥ / \mathrm{t}$ (with the water content of sludge $80 \%$ ). The operation cost is 120 245 $¥ / \mathrm{t}(80 \%$ meter to the water content of sludge).

Route Advantage. Anaerobic digestion is the anaerobic biochemical reaction of facultative bacteria and obligate anaerobic bacteria under anaerobic conditions, so that the organic matter in the sludge is degraded and become a stable substance in the environment, which is not easily corrupt and smelly. Most of the pathogenic bacteria and parasite eggs were killed. In the process of digestion, a certain amount of methane is produced, which is a kind of high quality clean energy. Not only can meet the digestive process to maintain the temperature required for thermal energy, but also to provide outside the system, is a reduction of carbon dioxide emissions of active and effective measures [4].

Problems. Most of the organic matter in the sludge is microbial cell substance, due to the cell wall package, is not conducive to biological degradation, Therefore, the sludge degradation rate is low, the sludge anaerobic digestion residence time is long and the reaction volume is big. In addition, the content of mud and sand in the sludge is higher, the organic matter is insufficient, and the biodegradability of the sludge is poor. This leads to the stability of the digestion equipment, and the rate of biogas production is generally lower than the foreign standards.

Aerobic Fermentation + Land Use. Operational Aspect. The route was dewatered sludge with water content of $80 \%$, and thermophilic aerobic fermentation was used as the raw material. When the amount of sludge is large, aerobic fermentation technology such as tunnel silo type and fermentation pool type can be selected. When the amount of sludge is small, the aerobic fermentation techniques such as membrane type, strip type and drum type can be selected [5]. Aerobic sludge fermentation stage has a long cycle, usually at 25 30 days. Because the sludge contains a lot of nitrogen, phosphorus, and various organic substances, it can provide essential nutrients for plant growth and improve soil texture. The sludge treated by aerobic fermentation can be used as fertilizer.

Cost Analysis. Affected by such factors as the scale of the project, the choice of concrete process and the location, the investment cost of the sludge composting project is about 200 700 thousand $¥ / \mathrm{t}$ (with the sludge moisture content of 80\%), and the operating cost is 60 200 ¥/t.

Route Advantage. The sludge can be used for soil improvement, as fertilizer for farmland and green garden city, and it has a certain ecological and economic benefits, at the same time meet the needs of recycling of resources and sustainable development. This kind of sludge treatment methods not only dispose of sludge, but also reduce the potential threat of sludge to the environment, and 
restore the ecological environment.

Problems. Firstly, sludge thermophilic aerobic fermentation technology needs more external energy, also need to consume straw, bran, sawdust, sawdust and other accessories. Therefore, it is necessary to consider the problem of local accessories resources.

Secondly, due to the confluence of municipal wastewater and industrial waste water, a large number of heavy metal ions are collected in sludge, which is difficult to remove. If the sludge containing a large number of heavy metal pollutants is used as raw material and processed as agricultural fertilizer, it will seriously endanger human health [6].

Thirdly, although it can still be used as a green fertilizer, aerobic fermentation is more expensive than other fertilizers. The fertilizer price is higher than ordinary fertilizer prices, so the market is small.

Incineration + Building Materials Utilization. Operational Aspect. Sludge of which dry basis calorific value above $8368 \mathrm{~kJ} / \mathrm{kg}$ can use this technology [7]. The depth of the concentrated sludge with water content of $97 \%$ is reduced to less than $60 \%$.The waste heat produced by sludge incineration is dried up, and the water content is further reduced to less than $40 \%$,and is burned in a fluidized bed incinerator. The inorganic sludge containing 20\% 30\%.After incineration, the ash mainly contains silicon, aluminum, iron, calcium and other compounds, which can be used as cement additive and preparation of light aggregate, and can also be used for firing brick, ceramsite. The heat generated by incineration flue gas waste heat boiler for heat recovery after anterior sludge drying. Not only can meet the needs of self-sustaining incineration, but also can provide a certain amount of waste heat, so that incineration costs are further reduced. The flue gas after treatment can meet the emission standards for emissions.

Cost Analysis. Sludge containing the front-end depth of dehydration, sludge incineration disposal project, the overall investment cost of 200 350 thousand $¥ / t$, operating costs of 260 350 $¥ / \mathrm{t}$.

Route advantage. Incineration can achieve stable and harmless disposal of sludge, and sludge reduction can be maximum, and it can greatly reduce the sludge follow-up disposal, as well as monitoring, management costs. So it is still competitive in cost. If the incineration products were identified as non-hazardous waste, it can be directly used as building materials, which conforms to the basic concept of low carbon economy, energy saving and environmental protection.

Problems. Incineration technology has huge investment in the early stage, and requires higher operation management at the later stage. It produces harmful tail gas when burned, mainly for nitrogen oxides, sulfur oxides, a small amount of particulate matter and dioxin.

\section{Results}

Firstly, because of the background of urban pipe network construction which is the interflow of rainwater and sewage, municipal and industrial wastewater, the simple introduction or copying of foreign technology shows the problem of inadequate applicability of China's national conditions in terms of technology, cost and management,. When we choose the appropriate technical route we should consider many aspects such as the characteristics of different technologies and the differences of regional economy, local government, financial resources, geography, population, climate and so on. Table 1 shows a comprehensive comparison of 3 sludge recycling technologies.

Secondly, conventional incineration will be the first choice for sludge treatment as well as burgeoning pyrolysis and carbonization. The three technologies occupy a small footprint, and has short treatment period、and it can relatively complete treatment. Especially in the face of similar refractory with high organic content or other special sludge, the effect of the advantages of sufficient to cover its cost disadvantage.

Thirdly, the application of new technologies in the field of sludge treatment and disposal will continue to be attempted. With the continuous development of unit technology and different requirements, more integrated technology routes will be developed, so as to have different characteristics and applicability. 
Table.1. Comprehensive comparison of sludge recycling technologies

\begin{tabular}{|c|c|c|c|}
\hline Technology & $\begin{array}{c}\text { Anaerobic digestion } \\
+ \text { mixed landfill } \\
\end{array}$ & $\begin{array}{c}\text { Aerobic fermentation } \\
+ \text { land use }\end{array}$ & $\begin{array}{c}\text { Incineration + building } \\
\text { materials utilization }\end{array}$ \\
\hline $\begin{array}{l}\text { Technological } \\
\text { Superiority }\end{array}$ & $\begin{array}{l}\text { The basic realization of } \\
\text { reduction and harmless, } \\
\text { can achieve recycling of } \\
\text { resources }\end{array}$ & $\begin{array}{l}\text { The basic realization of } \\
\text { reduction and harmless, } \\
\text { can achieve recycling of } \\
\text { resources }\end{array}$ & $\begin{array}{l}\text { Obvious reduction, fast } \\
\text { processing speed, } \\
\text { completely harmless and } \\
\text { waste heat can be used }\end{array}$ \\
\hline $\begin{array}{c}\text { Shale } \\
\text { Requirement }\end{array}$ & $\begin{array}{l}\text { The ratio of carbon to } \\
\text { nitrogen is above } 2030\end{array}$ & $\begin{array}{l}\text { The content of heavy } \\
\text { metals and organic } \\
\text { pathogenic substances } \\
\text { must be consistent with } \\
\text { the regulations }\end{array}$ & $\begin{array}{l}\text { Dry basis calorific value } \\
\text { above } 8368 \mathrm{~kJ} / \mathrm{kg}\end{array}$ \\
\hline Pretreatment & mechanical dehydration & Thickening dehydration & $\begin{array}{l}\text { Deep dehydration } \\
\quad+\text { heat drying }\end{array}$ \\
\hline $\begin{array}{l}\text { Capitalized Cost } \\
\text { (Thousand } ¥ / T \text { ) }\end{array}$ & $200 \sim 400$ & $250 \sim 450$ & $300 \sim 700$ \\
\hline $\begin{array}{c}\text { Running Cost } \\
(¥ / T)\end{array}$ & $60 \sim 120$ & $120 \sim 160$ & $120 \sim 250$ \\
\hline Shortcoming & $\begin{array}{l}\text { High sludge requirements, } \\
\text { subsequent disposal takes } \\
\text { up more land resources,, } \\
\text { high monitoring and } \\
\text { management costs }\end{array}$ & $\begin{array}{l}\text { Very high requirements } \\
\text { for mud, the need for } \\
\text { accessories, products } \\
\text { have no price advantage }\end{array}$ & $\begin{array}{l}\text { The high cost of early } \\
\text { investment, flue gas } \\
\text { treatment is difficult }\end{array}$ \\
\hline
\end{tabular}

\section{References}

[1] Wang Sheping, Cheng Xiaobo , Liu Xin'an, et al. Potential Hazard Analysis of the Sludge Treatment Process in Sewage Treatment Plant [J]. Municipal Technology, 2015,(02):164-168.

[2] He Qiang, Ji Fangying, Li Jiajie. Approach and New Technology of Sludge Treatment Disposal and Resource Utilization [J]. Water \& Wastewater Engineering, 2016, (02):1-3.

[3] Lv Fengjin, Han Yunping, Liu Junxin, et al. Research Progress on the Characteristics of Sewage Sludge and Its Anaerobic Digestion Performance [J]. Environmental Engineering, 2016, (S1): 780-785+467.

[4] Han Wenbiao, Wang Yiqi, Xu Xia, et al. Study on Biogas Production by Anaerobic Digestion of Excess Sludge and Organic Waste [J]. Renewable Energy, 2016, (05): 745 -748.

[5] Wang Shunhe, Zhang Yueyong, Li Xiaojing, et al. Characteristics of Aerobic Fermented Sludge and the Feasibility of Landscaping [J]. Environmental Engineering, 2015, (S1):586-588+609.

[6] Xue Wanlai, Ye Zhihan, He Chunli, et al. Assessment of Potential Ecological Risk of Sludge in Land Use [J]. Chinese Agricultural Science Bulletin, 2015,(09):207-211.

[7] Wen Zhe, Wang Bo, Feng Rong, et al. Brief Introduction of Municipal Sludge Drying and Incineration Technology and Process [J]. Engineering for Thermal Energy and Power, 2016, (09):1-8+129. 